\title{
Sarekat Islam Madura: Between Social Religious and Political Movements, 1913 - 1920
}

\section{Iswahyudi}

Yogyakarta State University, Indonesia

Email: iswahyudi@uny.ac.id

\begin{abstract}
:
Madura during the colonial period or at the turn of the 20th century, indicated that it was not a fertile ground for mass mobilization. Starting from the community because it is almost completely divided as a result of scattered settlements and scarcity of resources. The movement that rejects various kinds of prejudice is shown at a glance with the development of the Madura branch of the Sarekat Islam led by the hajj, so that the Dutch government still feels the symptoms of Islamophobia and is also supported by the small people, in this case oreng kenek with its distinctive ideology such as milleniarism and Islamic messianism. . The limitations of each kyai are closer to the peasants from the village, whereas a haji is generally a trader who lives in urban areas. So in this case a kyai is considered a power broker to mobilize the population, especially from among the peasants, while a haji acts as a cultural broker, especially for the revival of Islam. Related to the ideals of self-determination in politics, it is a reflection of the capabilities of the Madurese Sarekat Islam figures to the various social changes or modernity that were taking place at that time.
\end{abstract}

Keywords:

Sarekat Islam; Madura; oreng kenek; Kyai Taman; Haji Syadzili

\section{Introduction}

The first general congress of SI chaired by Cokroaminoto in the city of Surabaya on 26 January 1913 by bringing in delegates from Surabaya itself from other cities with a total membership of around 8,000 - 10,000 was considered a successful congress. Then the second congress held in Surakarta on March 23, 1913 resulted in a Centraal Committee or big committee with the election of Haji Samanhudi as chairman and Cokroaminoto as vice chairman. At that time the number of visitors also reached thousands of people (Wal, 1967:179). After the two congresses were held, the number of followers of the Sarekat Islam grew more and more, in Surakarta alone in May 1912 it had reached 12,000. Korver stated that the largest number of members was in Batavia, amounting to 77,000, followed by Palembang with 62,000, in Southeast Kalimantan with 50,000, and in Cirebon with 40,000. Then the number that is still considered high on average because it exceeds the 30,000 figure are in Bengkulu, Semarang, Rembang, Surabaya and Madura (Korver, 1985: 196-198). Overall the development of the members of the Sarekat Islam continued to show an increase from 1914, which numbered 444,251 people, in 1916 there were as many as 800,000 people and by 1919 it had reached 2,000,000 (Pringgodigdo, 1986: 6-8).

Such a large number at least reflects the existence of a form of awareness, either socially or politically, to rise to improve the level of life of the people who have been in trouble. This attitude by Suharjo, the head of the Surabaya branch of the Sarekat Islam, said that the Sarekat Islam was like the oppressed little people and with the capil Cekuthuk symbol or a kind of hat made of bamboo then became a symbol of the unity of the Sarekat Islam as an icon of resistance (Oetoesan Hindia, 24 Juni 1916). Sarekat Islam Madura experienced 
development after it was approved as a legal entity at the time of the congress in Surabaya. It was Haji Syadzili or Mas Gondosasmito who first established the Sampang branch of the Sarekat Islam in April 1913. As it is told, before Mas Gondosasmito performed the haj pilgrimage in Mecca, he worked as a school principal or a teacher in a government school in Sampang. He performed the pilgrimage when he was 25 years old or in 1911 and because of the bad news by the Dutch government, he finally resigned from his job. After marrying a rice trader, becoming an entrepreneur is the right thing for Haji Syadzili. At the same time, around 1913 his friend Pak Munah was the one who led him to join the Sarekat Islam ideology and at the same time became a member because both of them often went to Surabaya to meet Cokroaminoto (Amin, 1995: 61-78).

The city of Sampang was chosen as the initial establishment of Sarekat Islam because compared to other cities in Madura, Sampang was not a colonial city because there were not many Dutch people and was considered a marginal city. Even the city of Sampang, according to Rifai, is known as the city of oreng kenek, which is more a signal that strengthens that at the end of the 19th century the city of Sampang was categorized as one of the most prosperous cities in Madura, which gave rise to a middle class of indigenous people who were able to compete with Chinese population groups (Rifai, 2007; Kuntowijoyo, 2002: 83; Romli et al., 1994:23). The rapid development of the Sarekat Islam in the city of Sampang was also significantly related to the arrival of Kiai Mansur in April 1913 as a delegation from the leadership of the Central Sarekat Islam (CSI), namely Cokroaminoto, to take the oath of the new Sarekat Islam members. Even though it has not received the status as a formal legal entity, it will de facto become a milestone for the birth of the Madura branch of Sarekar Islam (Kuntowijoyo, 1989: 121). After the establishment of the Sarekat Islam Sampang, the development of the Sarekat Islam spread throughout Madura due to the influence of Haji Syadzili's propaganda which was able to approach oreng kenek groups, so that there was a modernization process in the arena of political organization in Madura. Another byword is that being a member of the Sarekat Islam for the oreng kẽnẽk is a channel of expression of a sense of oppression due to the old strict social stratification of the native rulers (ANRI, 1975: XXXIII).

\section{Research Methods}

To know about the Sarekat Islam in Madura: Between social religious and political movement 1913-1920 carried out using historical methods or historicalresearch methods which can be interpreted as a systematic collection of principles andrules intended to assist effectively in collecting historical source material, in assessing orcritically analyzing source content, and presenting a "synthesis" of the results achieved. This method is qualitative in the form of archive and library studies using written sources from the collections of the National Archives of the Republic of Indonesia and libraries in the form of archival materials, books, journals, and other printed sources (Garraghan,1957:33).

Primary and secondary data collection techniques were carried out through research on Archives and library materials by visiting the National Archives of the Republic of Indonesia (ANRI) Jakarta and various libraries and institutions that store reference books, articles in magazines and newspapers such as the National Library of the Republic of Indonesia in Jakarta and in other libraries. After the search for written materials has been completed, the next step is to select and verify the data and compile it into an article (Iswahyudi, 2020: 800) 


\section{Result and Discussion}

\subsection{The dynamics of the Sarekat Islam Madura}

In May 1913 a new branch of Sarekat Islam was established on the island of Sapudi, which in this case included the Sumenep district by Pak Bidri alias Abu Bakar from Jambuwir village and an Arab named Syekh Subidi from Gayam village (Rohmah,1977:40). Then successively following the establishment of the Sumenep branch of the Sarekat Islam which was founded by Haji Zainal Arifin on December 31, 1913 and two months later on February 1914, the Pamekasan branch of Sarekat Islam was established and on February 25, 1914 the Sarekat Islam Duko was one of the areas in Pamekasan district. Then on April 2, 1914 the Bangkalan branch of the Sarekat Islam was established (ANRI, 1975: XXXII-XXXIII).

All these branches of the Sarekat Islam in Madura have not yet obtained legal status because the Dutch Government was deliberately stalling for time in order to control and supervise the development of Sarekat Islam in Madura. The delay was based on various issues such as getting a promise from the Turkish state known as the Red Crescent to join Germany to win the First World War to help the costs of advancing the Sarekat Islam Madura (ARA,POKT,1913:952). Another consideration was the delay in giving the Dutch government legal status because it was very worried about Cokroaminoto's influence which was so idealized in Madura. The observation made by Resident Rinkes when jointly visiting the Madura area was that the name Cokroaminoto was mentioned as "Our Wisnu", the name with the words Cokro was Herucokro who was none other than a fair queen. In fact, because of the enthusiasm of the kẽnẽk members of the Sarekat Islam for the Sumenep branch, they used boat transportation to attend meetings or vergadering the Sarekat Islam in Situbondo in February 1915, just to see Cokroaminoto's face making a speech (Korver, 1985: 77-80).

To anticipate the rapid development of Sarekat Islam, the Dutch government also canceled requests for the establishment of new Sarekat Islam branches in Madura, including the cancellation of the establishment of Sarekat Islam branch of Telangu, Gapurana district, Sumenep district. The reason that was used as the basis was because the Telangu branch of the Sarekat Islam would be led by Sayid Mohammad Algadri, who was actually not only ethnic Arabs but also fired from the membership of the Sarekat Islam Sumenep (Kuntowijoyo, 1991: 84). This rejection is also not fundamental if the cancellation of Sarekat Islam Telangu is only due to its proximity to the Sarekat Islam Sumenep, so that the alleged concern of the Dutch government with teachers of Arab ethnicity such as Sayid Mohammad Algadri and the issue of pan-Islamism is correct (Oetoesan Hindia, 10 Maret 1919 No.43). When the Dutch government offered who was willing to replace its leader, the members of the Sarekat Islam Telangu refused and only accepted Sayid Mohammad Algadri. When the name Andawijaya was submitted, who was previously the secretary of the Sarekat Islam Telangu, the Dutch government did not agree because it had a bad record of being fired from its position as a Dutch police agent (Oetoesan Hindia, 28 Maret 1916 No.47).

In addition to the cancellation action, the Dutch government also took firm action against government employees who were members of the Sarekat Islam, including members of the Barisan corps, police agents and village heads. This was done because it was to anticipate that the influence of the Sarekat Islam would not penetrate the government employees. Apart from these firm actions, the government also exerted pressure on all government employees who were members of the Sarekat Islam as was the case with Raden Yudokusumo, a sergeant in the Barisan corps in Bangkalan district who was forced by his instructor captain to choose allegiance to Barisan or to Sarekat Islam. It turned out that Raden 
Yudokusumo firmly chose Sarekat Islam and was very loyal to Islam (Oetoesan Hindia, 2 April 1916 No.53).

Actions to hinder the development of Sarekat Islam in Madura were not only from the Dutch government, but also by indigenous officials who were afraid to lose power. For example, the Pamekasan district head argued that the people in his area were considered immature to join political organizations such as the Sarekat Islam. The district head is also worried that bad influences could threaten the population to undermine the government by using socio-political movements such as the Sarekat Islam to obstruct their interests and violate the law. This concern is also based on the experience of the Pamekasan regent that members of the Madura Islamic Sarekart often undermine the power of indigenous officials, so they often get targets of hatred from oreng kenek.

Thanks to pressures from the Kantoor voor Inlandsche Zaken or an advisory institution for government and men's affairs headed by an Adviseur voor Inlandsche Zaken or Minister for Indigenous Affairs who at that time was held by Hazeu, the incessant propaganda of the Sarekat Islam carried out by Haji Syadzili finally the Dutch government gave the Madura branch of the Sarekat Islam legal status. The announcement was made on April 3, 1915 for all branches in Madura, including the Sampang, Sapudi, Sumenep, Pamekasan, Duko, and Bangkalan branches of Sarekat Islam, except for the Sarekat Islam Telangu which was not authorized (ANRI. Besluit van Gouverneur Nederlandsch-Indie, Batavia, 3 April 1915. no. 47). After Sarekat Islam Madura received status from the Dutch government, Cokroaminoto appointed two CSI commissioners for Sarekat Islam Madura, namely Haji Syadzili in Sampang city and Hasan bin Semit in Bangkalan. These two figures are important because they are the pioneers of propaganda that are aggressively fighting for the Madura Islamic Sarekat, both at the central and local levels. At the central level it was proven that Haji Ahmad Sadzali was appointed a member of CSI along with Kyai Ahmad Dahlan from Yogyakarta, and Haji Hisyam Zaini from Surakarta based on the first Sarekat Islam national congress in Bandung in 1916 (Anonim, 1916: 69).

An indication that makes fragmentation in political events so complex and casuistic at the local level, namely Madura shows an interesting narrative especially in relation to the emergence of movements divided between religious and non-religious in nature. Religious movements are dominated by the role of the Sarekat Islam Madura, although by the middle of the 20th century it had experienced a decline. One of the religious political movements that had nothing to do with Sarekat Islam, was an incident in Prajan village, Camplong sub-district, Sampang. As according to Djoko Lelono, the incident was an internal competition between the two pesantren between Kyai Moh Zain from South Prajan and Kyai Langgar Tanah from North Prajan. Kyai Moh Zain was a Dutch espionage, on the other hand Kyai Langgar Tanah was assisted by local scholars, namely Kyai Langgar Cungkup Timur, Kyai Langgar Cungkup Barat, and Kyai Langgar Cungkup Barat. In addition to receiving many santri followers, the four scholars also agreed to rebel against the Dutch government. At its peak after the killing of Kyai Langgar Tanah, there was resistance around the village mosque of Prajan Selatan, many victims from both sides, approximately 60 people died, including Kyai Moh Zain. It is estimated that in the Prajan incident the Dutch government intervened and sided with Kyai Moh Zain for sending military soldiers and the Barisan corps, with reasons for security in Prajan (Lelono, 1947: 1 - 59). Likewise, when there were non-religious movements, the role of Sarekat Islam Madura still played little role, so that in its development there were balancing movements whose aim was the realization of independence in the Dutch East Indies. 
The decline of the Sarekat Islam in Madura was initially marked by a conflict that caused a split in leadership due to differences in the interests of social groups that were difficult to unite through the Sarekat Islam ideology. The first time conflict and division emerged was the Sumenep branch of the Sarekat Islam. At that time, the leadership of the Sumenep branch of the Sarekat Islam, Kyai Haji Zainal Arifin, received opposition from the younger generation, because they were considered to have diverted the organization's money and cooperative savings were used to pay for the pilgrimage to Mecca (Oetoesan Hindia, 10 Januari 1919, No.23).

As commissioners of CSI in Madura, Haji Ahmad Sadzali and Hasan bin Semit seem to support the younger generation of Sarekat Islam Sumenep. This proved to be of the opinion that Kyai Haji Zainal Arifin as the leader of the Sarekat Islam had a lot of influence from the regent of Sumenep because of his loyalty to the Dutch government, as when he supported HOS Cokroaminoto in his appointment as a member of the Volksraad. It is different from Hasan bin Semit, that supports the younger generation of Sarekat Islam Sumenep because they do not like Kyai Haji Zainal Arifin who applied the teachings of the Naqsyabandiyah tarekat to the Sarekat Islam organization (ANRI, Sarekat Islam Lokal. Penerbitan Sumber-sumber Sejarah No.7. Jakarta Arsip Nasional RI, 1975; 310).

After holding a meeting on February 2, 1919, the opposition movement of the younger generation Sarekat Islam Sumenep succeeded in overthrowing the leadership of Kyai Haji Zainal Arifin, because his position was replaced by Ario Condrosisworo, the youngest brother of the regent of Sumenep (Oetoesan Hindia, 17 Februari 1919 No. 33). Regarding this change of leadership, it proves that previously there had been competition, because Kyai Haji Zainal Arifin was known as a member of the Sumenep aristocracy as a teacher of the Naqsyabandiyah order, while Ario Condrosisworo was a follower of the Qadiriyah order who studied from Kyai Zainal Abidin in Kwanyar, Bangkalan (Bruinesen, 1922: 175-176).

In contrast to the Bangkalan branch of the Sarekat Islam, conflicts and splits began with the dismissal of the Regent of Bangkalan Surionegoro. Apart from being a long-tailed, this incident of dismissal also occurred for and against in public discussions. The Dutch government emphasized that Surionegoro's dismissal was because he was considered weak and powerless in managing the agenda for housing improvement and controlling disease outbreaks for his people (Oetoesan Hindia, 24 Oktober 1917 No. 41). Even the regent was rumored to have a second wife named Painah who got a bad record in the eyes of the community. Among other things, Painah was often discouraged as someone who became a mediator for Chinese merchants, and also often received pennies from related indigenous officials for his ease of contact with the regent, and even often displayed jewelery and other luxury objects that were suspected of being gifts. from Chinese traders in Bangkalan (Neratja, 5 September 1918 No.168, 8 September 1918 No. 171).

On August 28, 1918, the public was shocked by the news in the mass media regarding the dismissal of the Regent of Bangkalan Surionegoro. Then the Dutch government appointed Raden Tumenggung Suriowinoto, the former Sampang regent as his successor. Various indigenous press commented carefully on the incident of the dismissal. The newspaper Neratja wrote that the dismissal was based on morality issues (Neratja, 4 September 1918 No. 167, 8 September 1918 No. 171). Then the newspaper CSI (Oetoesan Hindia), apparently did not comment much on the dismissal of the district head. This was based on the fact that the Bangkalan regent was deemed not to have important affairs with the Sarekat Islam movement. However, in its development something unexpected happened, because the news of the dismissal had an uncomfortable impact on the indigenous officials in Bangkalan to respond 
and act (Oetoesan Hindia, 21 September 1918 No. 179). Due to the confusing and dilemma of the officials and the indigenous community, this resulted in a change because Sarekat Islam Bangkalan replaced the bupati who was fired. On the other hand, one of the articles in the Darmo Kondo newspaper criticized the president of Sarekat Islam Bangkalan, because regret for the dismissal was considered inconsistent and useless (Darmo Kondo, 25 September 1918 No. 108).

Then the division of the leadership of the Sampang branch of Sarekat Islam also occurred because there were differences in views on salt politics between Haji Ahmad Sadzali and R. Sosrodanukusumo. The conflict started when Haji Ahmad Sadzali was asked to sit as a committee assigned by the Dutch government to conduct research on the conditions of salt production in Madura. Based on the views of Haji Ahmad Sadzali, the results of the research show that salt producers in Madura residency by receiving a salt purchase price of $f .15$, - per person was eligible for approval at the Volskraad trial at the end of 1918. On the other hand R. Sosrodanukusumo strongly rejected Haji Ahmad Sadzali's proposal, even with a loud voice daring to oppose it. With the warm conditions at the trial, Haji Ahmad Sadzali felt that this action was considered inspired by Semaun and Darsono, so he decided to dismiss R. Sosrodanukusumo from the membership of the Sarekat Islam (ANRI, Sarekat Islam Lokal. Penerbitan Sumber-sumber Sejarah No.7, 1975:312-313). The result of the dismissal of R. Sosrodanukusumo turned out to have a long tail, because R. Sosrodanukusumo, assisted by his son Kaharkusuman, was persistent in opposing the demand for salt as proposed by Haji Ahmad Sadzali. Even at the end of 1920 Kaharkusuman succeeded in triggering a strike by the salt workers in the village of Krampon. The impact of the internal conflict among the Sarekat Islam elites, supported distrust of the lower currents, resulting in a decline in the number of members of the Sarekat Islam branch of Sampang (Oetoesan Hindia, 5 Juli 1920 No. 124 ; Parwata, 2010: 89).

Regarding the Sarekat Islam Pamekasan, there is not much news. Even after receiving official recognition from the government on February 9, 1914, the Pamekasan regent was still too worried because the people were considered not ready to join political organizations like Sarekat Islam. One of the complaints addressed to the government in 1920 was not so harsh, because it only protested against the biased distribution of the rice trade in favor of Chinese traders (ANRI, Mailrapports No. 93 1922). Perhaps after the Duko incident, the Pamekasan branch of the Sarekat Islam was considered to have no significant meaning in the political arena in Madura. It's just that it was stated that one of the leaders was R. Asmorokusumo, who was considered unable to fight for the interests of orẽng kẽene $k$ individuals. This has always been scorned by members of the Sarekat Islam Duko, followers of Kyai Taman, that the Pamekasan branch of the Sarekat Islam is only a "Sarekat Ambtenaar", which means only fighting for the interests of the upper class or the parjaji class (ANRI, Sarekat Islam Lokal. Penerbitan Sumber-sumber Sejarah No.7, 1975: 314; Kuntowijoyo, 2002: 519).

\subsection{Kyai Taman Movement And Resistance To Salt Monopoly}

Incidents involving various negative prejudices against the bumiputera population include what happened when the Dutch government refused to ratify the Sarekat Islam Duko. However, in the end, due to pressure from the indigenous affairs office, Sarekat Islam Duko also obtained legal status on the condition that its activities were limited to the Bunder area (ANRI. Besluit van der Gouverneur General van de Nederlandsch Indie. Batavia 3 April 1915 No. 47). The location of Duko was actually in the Pamekasan area, but because it was considered different from the other Madura Islamic Sarekat Islam, there was a debate among colonial officials. Sarekat Islam Duko was led by Kyai Taman who was actually known as a hardtempered and anti-Dutch person. The reason that the ratification was not accepted was 
because from the list of 12 functionaries they did not have the status and title of nobility, so that Kyai Taman was considered a high-ranking orẽng kẽenek (ANRI, Sarekat Islam Lokal. Penerbitan Sumber-sumber Sejarah No.7 1975; 315).

The signs of Kyai Taman's radicalism were actually known by the Dutch government, as there were three methods to fight for the oreng kenek at that time. First, Kyai Taman supports the Madura Dipo movement, a movement that seeks to change and democratize the Madurese language by erasing the strata of the language. Second, supporting cultural movements assisted by Sosrodanukusumo. In this case the cultural programs carried out by Kyai Taman are aligned with his political programs, namely that the youth are actually enthusiastic about joining Sarekat Islam but are confused because there is pressure from local authorities. This made Kyai Taman later confess that he was a messiah and distribute Sarekat Islam membership cards to his followers with Islamic labels. Among other things, the card is called a "power card" which means that if someone has it, the person concerned will be free from tax payment obligations. The Dutch government considers this card to be a card from CSI which is called the "Banteng card" because there is a bull symbol on it. Inside this bull card is also written with Arabic scriptures and on the outside of the mouth of the bull are also written three slogans in Arabic script which reads "victory, strength, and will" (kemenangan, kekoeatan, dan kemaoean). In connection with this card, CSI charged a replacement fee of 53 cents, however, by Kyai Taman, it was increased to 80 cents to f.1, -, even up to f 1.60, (ANRI, Sarekat Islam Lokal. Penerbitan Sumber-sumber Sejarah No.7, 1975; 319).

Furthermore, Kyai Taman also told his followers that in 1920 the Dutch government would be replaced by a new government that exempted taxes and various other levies. At the same time, Kyai Taman also collects dues every week of 5 to 10 cents from his followers to buy weapons, especially brown pistols to fight the Dutch. Anyone who refused to become a member of the Sarekat Islam was considered an infidel. Even after the end of the Dutch government, it was said that there were no more officials who were subordinate to the Dutch government, such as wedono and wedono's assistant. If Kyai Taman succeeds in becoming king, the people who become his followers will get a position.

The movement concerning positive self-identity for the Sarekat Islam Madura is associated with awareness in responding to modern education and its strength in maintaining religious values. As it is known that before the introduction of Western education in Madura, the only teaching institution that existed was the Islamic boarding school, so that in order to recruit teachers, starting in 1853 the government provided scholarships to Madurese to attend teacher training in Surakarta (Kuntowijoyo, 2002: 197).

The application of the salt monopoly in Madura is a reflection of the nature of the colonial system that was applied in the colony. The Dutch government in exercising monopoly was always delegated by contracting out to other parties, which were usually groups of Chinese or other Asian people (V reemde oosterlingen). Various monopolies that are contracted apart from salt include; opium sales, arak production, pawnshops, management of gambling, bird nests, road taxes, tobacco excise, and cattle slaughter (Encyclopaedie van Nederlandsch Indie 1899, Vol I: 157-163). The salt monopoly was formally formed with a law stating that the Dutch East Indies government appointed one of its territories, namely the island of Madura, obliging its people to produce salt for the benefit of the population as well as for the government. This was based on the fact that after the Dutch government took power in Madura, the people who used to be peasants working on the indigenous rulers were also immediately delegated to work on the salt fields. In this case the people are completely not allowed to sell salt but only get a license (pepel) to produce salt. One of the institutions that 
deals with salt production is under the Ministry of Education, Religious Affairs and Crafts (Departement van Onderwijs, Eeredients en Nijverheid) which is directly under the supervision of Madurese residents. To avoid maladministration and the realization of professionalism, salt management is left to a salt company organization called zoutregie (Braam ,1916-1917:100).

The tendency to monopolize salt, especially on the island of Madura, was carried out because the net profit every year from 1916 to 1920 averaged 9 million guilders, making it tempting to control it. The decline in the welfare of salt farmers is also determined because there are no other livelihoods, so that if a crop failure occurs it is a disaster. Usually, the poor salt farmers can see if they will return the capital to start production, they are forced to borrow debts from loan sharks, usually Chinese and Arab people with high interest. A report shows that in 1915 the salt farmer borrowed money f.10, f.17, and $\mathrm{f}$ 60, and then had to pay it back in multiples of $\mathrm{f}, 14, \mathrm{f}, 34$, and $\mathrm{f}, 100$. fraudulent because he claims to be a trader who buys salt at low prices to producers and sells it to the government at the official price. As happened in Pamekasan, by buying salt for $\mathrm{f} 7$, per shake and selling it to the government at a standard price of $\mathrm{f}$ 10.- (Droste, 1921 No. 11: 215).

From the other side, namely from the labor group, there was also a deterioration in inhuman life, because salt production was not only capital intensive but also labor intensive, so that salt farming in Madura showed the true exploitation of colonialism. Starting from the salt production process in Madura which is related to the labor factor as mentioned above, Sarekat Islam Madura appears to fight for the fate of salt farmers and their workers, especially to increase the price of salt, so that it is scheduled as a salt policy. The demand for an increase in the price of salt was carried out in view of the existence of strict regulations from the government regarding the manufacture of salt. These regulations include repairing salt ponds, cleaning up expensive waste and fraudulent weighing by government workers, all of which make production less profitable for salt makers. Due to this fact the salt makers tried to disobey the regulations and even in some areas there were strikes. However, this did not solve the problem because their salt production was not of good quality, ultimately it was not accepted by the government and after the rainy season arrived the salt dissolved in the rainwater (Braam,1916-1917:103).

With the difficulties faced by the salt makers, then Sarekat Islam Madura appeared as a mediator to convey the request to the government. The person who is considered responsible is Haji Ahmad Sadzali, so thanks to his agreement with H.O.S. Cokroaminoto, after holding a discussion with salt producers throughout Madura, wants to increase the purchase price of salt from f.10,- - to f. 20, - each koyang (ANRI, Sarekat Islam Lokal. Penerbitan Sumber-sumber Sejarah No.7, 1975; 314). The meeting took place in Duko on December 16, 1916 and the matter was brought to the Volksraad by Cokroaminoto. Even in early 1917 Cokroaminoto had also met the Governor General to discuss the price of salt in Madura Oetoesan Hindia 8 Maret 1917 No. 47).

The response of government officials to requests for price increases submitted at the end of 1917 came from the Director of the Salt Service, W. van Braam. The government through Van Braam rejected CSI's request and stated that the research conducted by Haji Ahmad Sadzali could not be trusted. The government considers that Haji Ahmad Sadzali only represents the interests of the salt field owners, but forgets the interests of the workers, who mostly consist of poor people. Starting from this rejection, when it was continued at the second volksraad session discussing salt politics, it took place in Sampang on January 18, 1918. The essence of the meeting was that there were two groups, namely between Van Hinloopen Laberton and Abdul Muis. The Hinloopen Laberton group wanted the salt to be increased to 
f, 15, - per shake, while the Abdul Muis group wanted f. 25, - per shake. Both of them have their respective alibis for the Laberton group, which is sufficient to get the results, while the Abdul Muis group prefers the development of the free labor market because the Madurese are accustomed to creating economic stability in their area, for example by having to go overseas for sufficient needs.

Responding to Volskraad's decision, Sarekat Islam Madura held various meetings in three places, namely in Sampang, Sumenep and Pamekasan. The meeting on 5 December 1918 in Sampang was attended by 448 salt field owners and workers from 23 villages and was considered to represent 15,000 votes. Then the meeting in Sumenep on December 6, 1918, was attended by 257 people from 29 villages, who were considered to represent 25,000 votes. Next was a meeting in Pamekasan on 8 December 1918 which was attended by 325 people from 33 villages and considered to have represented as many as 20,000 votes. Based on the results of these meetings, it was decided that the Madura Islamic Sarekat would continue to file demands for another price increase but the amount was according to the Volskraad wishes (Oetoesan Hindia, 19 Desember 1918 No. 240).

Considering that the meetings were conducted in an orderly manner, the Dutch government responded with pleasure and immediately formed a commission. Through the decree the commission consisted of seven people and four Dutch officials, namely; W. van Braam as chairman, W.H.J. Van Straaten, C.H.H, Snell, and A.J. Speel. Then the three people represent the indigenous population, namely; R. Sastrowijono from members of the Volskraad, Haji Ahmad Syadzali representing the Sarekat Islam Madura, and Haji Abdullah Buserahim. However, in a short time, Haji Abdullah Buserahim passed away and no one replaced him.

The problem with the politics of salt being brought to the Volksraad was as might be expected due to the stronger position of the government in the trial so that for various reasons accusing the commission's performance of being ineffective it resulted in a floating decision. The problem became complicated because of the issue of revenge from one of the members of the Sarekat Islam Madura, namely Sosro Danukusumo who rejected and doubted Haji Ahmad Syadzali in fighting for salt politics in Madura, then after waiting until 1920 a petition from CSI and Sarekat Islam Madura about demands to increase the purchase price salt from f.10, - to f.25, - has never been realized, so it has an impact on signs of decline of the Sarekat Islam in Madura (Kuntowijoyo, 1989: 70).

\section{Conclusion}

The success of the Sarekat Islam Madura in establishing many branches and gaining followers in large numbers is due to the vision and mission of the Sarekat Islam which is to popularize the emancipation and religious movements, so that based on Islamic teachings it is appropriate to eliminate discrimination and injustice. Apart from that, technically, the appearance of the Cokroaminoto figure has had a significant impact on the progress of the Sarekat Islam, when conducting vergaderingen or large meetings is something synchronous because Islam is a dakwah religion so that anyone can do it.

The movement that rejects various kinds of prejudice is shown at a glance by the development of the Madura branch of Sarekat Islam led by the hajj, so that the Dutch government still feels the symptoms of Islamophobia and is also supported by the small people, in this case oreng kenek with its distinctive ideology such as milleniarism and Islamic messianism. . Apart from the leaders and members of the Sarekat Islam Madura, it consists of 
pilgrims as well as kyai or scholars, both of whom are known to be devout religious people. The limitations of each kyai are closer to the peasants from the village, whereas a haji is generally a trader who lives in urban areas. So in this case a kyai is considered a power broker to mobilize the population, especially from among the peasants, while a haji acts as a cultural broker, especially for the revival of Islam.

Related to the ideals of self-determination in politics, it is a reflection of the capabilities of the Madurese Sarekat Islam figures to the various social changes or modernity that were taking place at that time. Starting from the beginning of the Sarekat Islam or reflected in its first congress in Surakarta, Cokroaminoto declared that Sarekat Islam was not political and it was impossible to want a revolution. However, in the next development, namely when the congress in Bandung in 1916 Cokroaminoto began to awaken and emphasize the Sarekat Islam citizens to choose a political step towards independence. Simultaneously with the formation of the volksraad or people's council in 1917 it was actually not something ideal, but it must be welcomed that this institution was the only hope to deliver independence.

The impact of the Bandung congress in 1916 made it clear that the orẽng kẽeñe understood very well about modern organizations as activities of the Sarekat Islam. Meetings to discuss everyday issues related to the living conditions of the population such as home improvement campaigns, cattle castration, prevention of corn disease, paying taxes, caring for and being responsible for women is a perfect opportunity for the outpouring of discontent with the government. One of the dissatisfaction and striving for self-determination as an icon of Madurese political consciousness is the issue of the salt monopoly.

\section{References}

Abdullah, Taufik (1983). Tradisi dan Kebangkitan Islam di Asia Tenggara. Jakarta: LP3ES

Amin, Mansyhur (1995). H.O.S. Tjokroaminoto: Rekonstruksi Pemikiran dan Perjuangannya. Yogyakarta: Cokroaminoto University Press

Anonim, "De Uitzwermende Madoereezen" in Indische Courant, 24 Mei 1932. No. 207

Anonim, "Madoera Belangen I: Rond de Economische Greens", in Soerabaiasch Handelsblad, 13 Mei 1933. no. 109.

Anonim, "Pamekasan", dalam Soerabaiasch Handelsblaad, 22 Januari 1935. No. 17.

Anonim, Babad Madura, alih bahasa Indri Nitriani dan Moelyono Sastro Naryatmo (Jakarta:

Depdikbud:M Proyek Penerbitan Buku Sastra Indonesia dan Daerah, 1981).

Anonim, Sarekat Islam 1'Nationaal Conggres 1916, ( Batavia; Landsdrukkerij, 1916)

ANRI, Persoverzicht in Het Kolonial Tijdschrift, no. 2, tahun 1913 hlm. 758.

ANRI, Verslag van Dients der Zoutregie en van de Daarbij Behoorende Afdeling: Vervoer en Verkoop, 1916-1917

ANRI, Besluit van der Gouverneur General in Nederlandsch Indie. Batavia 3 April 1915. no. 47

ANRI, Besluit van Gouverneur Nederlandsch-Indie, Batavia, 3 April 1915. no. 47

ANRI, Mailrapport No. 93, 1922

ANRI, Sarekat Islam Lokal. Penerbitan Sumber-sumber Sejarah No.7. Jakarta Arsip Nasional RI, 1975.

ARA, POKT. Persoverzicht in Het Koloniale Tijdschrift No. 2 over 1913

Boomgaard, Peter \& Ian Brown, eds,(2000). The Economics of Southeast Asia in the 1930s Depression .Singapore: ISEAS

Braam, W. van, "Een en Ander Over den Zoutanmaak der Bevolking op Madoera", in Koloniale Studien I, 1916-1917

Brugmans, I.J (1987). Politik Etis Dan Revolusi Kemerdekaan. Jakarta: Yayasan Obor Indonesia 
Bruinessen, Martin van (1992). Tarekat Naqsyabandiyah di Indonesia: Survey Historis, Geografis dan Sosiologis. Bandung: Penerbit Mizan

Cribb, Robert (1994). The Late Colonial State In Indonesia, Political and Economic Foundations of the Netherlands Indies 1880 - 1942. Leiden: KITV Press

Djaya, Tamar, Tahun 1905 Hari Kebangkitan Nasional (Jakarta: Prasaran Seminar Sejarah Perjuangan Islam 7-10 Mei 1971)

Droste, "Verslag Omtrent den Inlandschen Handel in de Residentie Madoera", in Blaadje van de Centrale Kas, 1921. no. 11

Encyclopaedie van Nederlandsch Indie, Vol I ('s-Gravenhage: Martinus Nijhoff, 1918)

Encyclopaedie van Nederlandsch-Indie, Suplemen, Vol. VI ('s-Gravenhage: Martinus Nijhoff, 1938)

Garraghan, G. J. (1957). A Guide To Historical Method. New York: Fordham University Press

Geertz, Clifford (1960). The Javanese Kijaji: The Changing Role of a Cultural Broker", Comparative Studies in Society and History II.

Ingleson, John (2013). Perkotaan, Masalah Sosial \& Perburuban Di Jawa Masa Kolonial, terjemahan Iskandar P, Nugraha .Jakarta: Komunitas Bambu.

Ingleson, John "Urban Java During the Depression", in Journal of Southeast Asian Studies, September 1988, Vol. 19. No. 2, hlm. 306

Iswahyudi (2020), Toward Remediation of Indonesian New Fine Arts. Britain International of Linguistics, Arts and Education (BIoLAE) Journal Vol. 2, No. 3, November 2020 : 797-809 DOI: https://doi.org/10.33258/biolae.v2i3.332

Kemp, P. H. van der (1894). Handboek toet de Kennis van 's Lands Zoutmiddel in Nederlandsch-Indie: Eene Economisch-Historisch Studie. Batavia: G. Kolff \& Co.

Killian, H.,N (1897). Madoereesche Spraakekunst, Vol.2. Batavia: Landsdrukkerij

Korver, A.P.E (1985). Sarekat Islam: Gerakann Ratu Adil, Translated by Grafitipers. Jakarta: PT. Temprint

Kuntowijoyo (1989). "Islam dan Politik: Gerakan-Gerakan Lokal Sarekat Islam di Madura 1913-1920" dalam Taufik Abdullah and Sharon Siddique, ed, Islam and Society in Southeast Asia, terjemahan Rokhman Akhwan .Jakarta: LP3ES

Kuntowijoyo (1991). Paradigma Islam: Interpretasi Untuk. Aksi . Bandung: Penerbit Mizan

Kuntowijoyo (2002). Perubahan Sosial Masyarakat Agraris Madura 1850 - 1940. Yogyakarta: Matabangsa

Kwantes, R.C, De Ontwikkeling van De Nationalische Beweging in Nederlandsch-Indie. Eerste Stuk 1917 - medio 1923 (Groningen; Tjeen Willink)

Lelono, Djoko (1947). Pablawan Madura. Jogjakarta: N.V. Tjatur

Nasihin (2012). Sarekat Islam Mencari Ideologi 19243 - 1945 .Yogyakarta: Pustaka Pelajar

Noer , Deliar (1982). Gerakan Moderen Islam di Indonesia 1900 - 1942 .Jakarta: LP3ES

Notulen : Der Vergadering Van Den Gewestelijken Raad Van Madoera, Gehouden op Zaterdag 28 September 1918. Magelang: N.V. Stoomdrukkerij H.V. Maresch

Parwata (2010). Monopoli Garam di Madura. Jember: Visart Global Media

Pringgodigdo, A.K (1986). Sejarah Pergerakan Rakyat Indonesia, cetakan XI. Jakarta: Dian Rakyat

Rapport van de Madoera Commisie: Ingesteld bij Gouvernement beshit van 5 Maart 1919 no. 35 (Landsdrukkerij -Weltevreden, 1920)

Rifai , Mien R. (2007). Manusia Madura. Yogyakarta: Nuansa Aksara

Rochmah, Nur, Perikanan Laut di Pulau sapudi dan Kangean akhur Abad XIX-XX (Unpublished Thesis, Fakultas Sastra, UGM, 1977)

Romli, Mohammad et al. (1994). Hari Jadi Sampang . Sampang: Pemerintah Daerah Tingkat II sampang - Suaka Peninggalan Sejarah dan Purbakala Jawa Timur

Staatsblad V an Nederlandsch Indie No. 73, 1882

Surat Kabar Oetoesan Hindia 10 Maret 1919, no. 43 
Surat Kabar Darmo Kondo, 21 Desember 1918.No. 142.

Surat Kabar Darmo Kondo, 25 September 1918. no. 108.

Surat Kabar Neratja, 30 November 1918. No. 226.

Surat Kabar Neratja, 4 September 1918. no. 167.

Surat Kabar Neratja, 5 September 1918.no.168

Surat Kabar Neratja, 8 September 1918. no. 171.

Surat Kabar Oetoesan Hindia 1 Agustus 1914, no. 134

Surat Kabar Oetoesan Hindia 12 Agustus 1914. no. 155

Surat Kabar Oetoesan Hindia 16 Juni 1916. no. 113

Surat Kabar Oetoesan Hindia 21 Januari 1917. no. 14

Surat Kabar Oetoesan Hindia 24 Juni 1916

Surat Kabar Oetoesan Hindia 24 Oktober 1917. no. 41

Surat Kabar Oetoesan Hindia 27 Juni 1918. no. 122

Surat Kabar Oetoesan Hindia 27 Maret 1914, no . 65

Surat Kabar Oetoesan Hindia 28 Maret 1916, no. 47.

Surat Kabar Oetoesan Hindia 30 November 1915. no. 228

Surat Kabar Oetoesan Hindia 30 Oktober 1914. no.192

Surat Kabar Oetoesan Hindia 5 September 1914, no. 162

Surat Kabar Oetoesan Hindia 8 Agustus 1917.no. 47

Surat Kabar Oetoesan Hindia 8 Maret 1917, no, 47

Surat Kabar Oetoesan Hindia 9 Oktober 1918,. No. 148

Surat Kabar Oetoesan Hindia 10 Januari 1919. no. 23

Surat Kabar Oetoesan Hindia 11 Oktober 1918, nomor Ekstra

Surat Kabar Oetoesan Hindia 14 Agustus 1918. no. 154

Surat Kabar Oetoesan Hindia 16 April 1918. no. 74

Surat Kabar Oetoesan Hindia 17 Februari 1919. no. 33

Surat Kabar Oetoesan Hindia 19 Desember 1918, no. 240

Surat Kabar Oetoesan Hindia 21 September 1918. no. 179

Surat Kabar Oetoesan Hindia 23 Desember 1919. No. 67.

Surat Kabar Oetoesan Hindia 5 Juli 1920. No. 124.

Surat Kabar Oetoesan Hindia, 2 April 1916, no. 53

Tirtodiprodjo, Susanto (1968). Sedjarah Pergerakan Nasioinal Indonesia. Djakarta: Pembangunan Tjokroaminoto, H.O.S (1955). Tafsir Azas Dan Profram Tandhim PSII. Jakarta: Lajnah Tanfidiyah PSII

Tjokroaminoto, H.O.S, Islam dan Sosialisme. Jakarta: Perhimpunan Sejarah Revolusi Indonesia, t. t.

Wal, S.L.van der (1967). De Opkomst van Nationalistische Beweging in Nederlandsch-Indie. Groningen: J.B. Wolters

Wiyata, Latif (2002). Carok: Konflik Kekerasan dan Harga Diri Orang Madura. Yogyakarta: LKIS 